\title{
$\begin{array}{ll}\text { Research Square } & \begin{array}{l}\text { Preprints are preliminary reports that have not undergone peer review. } \\ \text { They should not be considered conclusive, used to inform clinical practice, } \\ \text { or referenced by the media as validated information. }\end{array}\end{array}$
}

\section{Resistance Traits and Molecular Characterization of Multidrug-resistant Acinetobacter baumannii Isolates from an Intensive Care Unit of a Tertiary Hospital in Guangdong, Southern China}

\section{Zhuo-Ran Chen}

The First Affiliated Hospital of Shantou University Medical College

Hui-Wu Guo

The First Affiliated Hospital of Shantou University Medical College

Qing Pan

Shenzhen University

Mao-Zhang Fu

The First Affiliated Hospital of Shantou University Medical College

\section{Ying-Kui Qiu}

The First Affiliated Hospital of Shantou University Medical College

Jun Liu

The First Affiliated Hospital of Shantou University Medical College

Nai-Kei Wong

The Third People's Hospital of Shenzhen

\section{YuanChun Huang ( $\nabla$ ychun_h@126.com )}

The First Affiliated Hospital of Shantou University Medical College https://orcid.org/0000-0001-81490168

\section{Research Article}

Keywords: Acinetobacter baumannii, antimicrobial resistance, resistance genes, healthcare associated infection, intensive care unit

Posted Date: August 5th, 2021

DOl: https://doi.org/10.21203/rs.3.rs-638208/v1

License: (c) (i) This work is licensed under a Creative Commons Attribution 4.0 International License. Read Full License 
Version of Record: A version of this preprint was published at International Microbiology on January 31 st, 2022. See the published version at https://doi.org/10.1007/s10123-022-00233-0. 


\section{Abstract}

\section{Purpose:}

This study aims to characterize antimicrobial resistance (AMR), with particular reference to carbapenems and aminoglycosides, in MDR A. baumannii isolates recovered from an intensive care unit in a tertiary hospital.

\section{Methods:}

A. baumannii ( $n=95$ strains) isolated from patients were subjected to antimicrobial susceptibility test (AST) by Vitek 2 Compact system to determine minimum inhibitory concentrations, followed by genotyping by enterobacterial repetitive intergenic consensus-PCR (ERIC-PCR). Resistance genes of interest were PCR-amplified and sequenced.

\section{Results:}

All isolates were qualified as MDR, with a resistance rate of $>80 \%$ to 8 antimicrobials tested. In terms of beta-lactamase detection, the $b / a_{O X A 23}$ and $b / a_{T E M-1}$ genes were detected frequently at $92.63 \%$ and $91.58 \%$, respectively. The metallo- $\beta$-lactamase genes $b / a_{I M P}, b / a_{V I M^{\prime}}$ and $b / a_{N D M}$ were undetected. Aph (3')I was detected in 82 isolates (86.32\%), making it the most prevalent aminoglycoside-modifying enzyme (AMEs) encoding gene. In addition, ant ( $\left.3^{\prime \prime}\right)-/$ was detected at $30.53 \%$, while $26.32 \%$ of the strains harboured an aac ( $\left.6^{\prime}\right)-1 b$ gene. ERIC-PCR typing suggested moderate genetic diversity among the isolates, which might be organized into 10 distinct clusters, with Cluster $A$ ( $n=86$ isolates or $90.53 \%$ ) being a dominant cluster of epidemic clones.

\section{Conclusions:}

Substantial fractions of the A. baumannii strains prevailing in the ICU were MDR clones exhibiting extremely high resistance to carbapenems and aminoglycosides as monitored throughout the study period. They principally belonged to a single cluster of isolates carrying $b / a_{O X A 23}$ and $\operatorname{armA}$ co-producing different AMEs genes.

\section{Declarations}

Funding This work was supported by 2020 Li Ka Shing Foundation Cross-Disciplinary Research Grant (2020LKSFG06A) , a grant from Medical Science and Technology Foundation of Guangdong Province (B2018168), China, and Scientific Research Project of Hunan Provincial Department of Education (18C1145).

Competing interests The authors declare no competing interests. 
Code availability Not applicable

Authors' contributions Yuan-Chun Huang designed the experiments, carried out the study, interpreted the data and reviewed the manuscript. Zhuo-Ran Chen, Hui-Wu Guo designed, performed the experiments and wrote the paper. Jun Liu, Mao-Zhang Fu, Ying-Kun Qiu, Qing Pan collected and analyzed the data. All authors read and approved the final manuscript.

Ethics approval Not applicable

Consent to participate Not applicable

Consent for publication Not applicable

Acknowledgements Nai-Kei Wong modified the manuscript.

\section{Introduction}

Acinetobacter baumannii (A. baumannii) is an opportunistic pathogen adept at colonizing and thriving in the hospital environment. In the recent decade, carbapenemase-producing multidrug resistant (MDR) $A$. baumannii has emerged as a prominent cause of healthcare-associated infections (HAls) notably at intensive care units (ICUs), whose incidence seems to be ascending alarmingly in parts of China (He C et al. 2011; Li Y et al. 2018; Mariana Bitrian et al. 2012; Behdad R et al. 2020). Patients undergoing invasive procedures, immunosuppressive therapy or treatment with broad-spectrum antibiotics are vulnerable to HAls cause by $A$. baumannii, particularly in the contexts of ventilator-associated pneumonia, bacteremia, septicaemia, urinary tract and wound infections (Mariana Bitrian et al. 2012; del Mar Tomas M et al. 2005; Freire MP et al. 2016; Carmen Gomez-Arrebola et al. 2021).

By virtue of its extraordinary aptitude to survive in the hospital environment and to develop extremely high resistance to an array of common antibiotics including aminoglycoside and carbapenem classes of antibiotics, $A$. baumannii has become a major challenge to medical care at the ICU (Shimose LA et al. 2016; Molter $G$ et al. 2016; Shamsizadeh Z et al. 2017). One of the most prevalent sequence types (ST) of epidemic clones in China is ST208, which has gained notoriety for causing outbreaks in local ICUs (Bahador A et al. 2015). Analysis on genomic relatedness among clinical isolates is necessary for determining an epidemic strain, as a first step toward informed diagnosis and anti-infective countermeasures.

Although substantial efforts have been made over the years in monitoring the epidemicity and AMR trends of $A$. baumannii in China, the scope of previous studies tends to be limited to highly populous urban centers in northern and eastern China (Ning NZ et al. 2017; Zhou K et al. 2018). In southern China including Guangdong province (population 108.5 million), where the humid subtropical climate indeed favors microbial growth, epidemiological surveys on A. baumannii in HAls were only with moderate frequencies and again covered only very large urban centers such as Guangzhou (population 14.9 million)(Zhou Y et al. 2015; Li Y et al. 2013). In contrast, studies on HAls by A. baumannii and underlying 
mechanisms of AMR are otherwise scant in other Chinese regions overlooked in epidemiological survey. In this regard, we undertook the current study to examine the AMR traits, molecular determinants of AMR and clonal relationship of $A$. baumannii strains isolated from an ICU of a teaching tertiary hospital in the Chaoshan metropolitan area (13.93 million residents) in Guangdong province, southern China. We found that the isolates $(n=95)$ generally exhibited very high resistance to most of the commonly used clinical antibiotics including aminoglycosides and carbapenems, carried blaOXA23, blaTEM-1 and aph (3')-I as major resistance genes and consisted mostly of strains belonging to a single dominant cluster (Cluster $A$ in ERIC-PCR analysis).

\section{Materials And Methods}

\section{Research settings and bacterial isolates}

This study was conducted at the ICU of a tertiary-level teaching hospital affiliated to the Shantou University Medical College (SUMC) in Shantou city in Guangdong, a populous province in southern China. The hospital (1816 inpatient beds) serves the Chaoshan metropolitan area in eastern Guangdong. A total of 95 non-duplicated $A$. baumannii isolates were systematically collected from patients' samples during the period of January $1^{\text {st }}$ to December $31^{\text {st }}, 2015$. This study had been reviewed and approved by the Research Ethics Committee of the First Affiliated Hospital of Shantou University Medical College. The study was given a waiver of informed consent on the ground that it focuses only on characterizing bacterial isolates and involves no patient's information.

\section{Antimicrobial susceptibility}

All isolates were first identified by using Vitek 2 Compact system (bioMérieux, France) and their antimicrobial susceptibility profiles obtained by using the Gram negative susceptibility cards (GN16 cards), according to the manufacturer's instructions. Antimicrobial susceptibility test (AST) results for MICs (minimum inhibitory concentrations) were interpreted according to the criteria recommended by the Clinical and Laboratory Standards Institute (CLSI 2015). Additional validation for $A$. baumannii was done by PCR to test for the intrinsic bla ${ }_{O X A 51}$ gene. Confirmed $A$. baumannii isolates were stored at $-80^{\circ} \mathrm{C}$ for subsequent experiments.

\section{Detection of antimicrobial resistance genes}

Whole genomic DNA was extracted by using TIANamp Bacteria DNA kit (Tiangen Biotech, China), according to the manufacturer's instructions. Detection of antimicrobial resistance (AMR) genes by PCR amplification was carried out with specific primers (See details in Table 1) to screen for the following genes of interest: extended-spectrum $\beta$-lactamases (ESBLs) encoding gene $\left(b / a_{T E M-1}, b / a_{\text {shv }}\right)$, metallo- $\beta$ lactamases encoding genes $\left(b / a_{I M P}, b / a_{V I M-2}, b / a_{N D M-1}\right)$, cephalosporinase encoding gene $\left(b / a_{A D C}\right)$, OXA

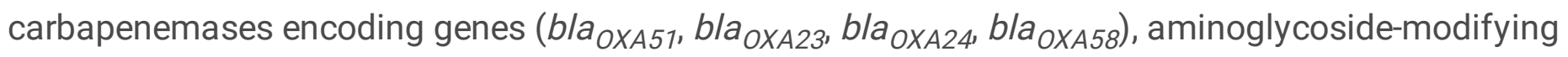
enzyme (AME) encoding genes ( $\operatorname{aac}\left(6^{\prime}\right)-1 b$, ant $\left.\left(3^{\prime \prime}\right)-1, \operatorname{aph}\left(3^{\prime}\right)-1\right)$ and 16s rRNA methylase encoding gene 
$(\operatorname{armA})$ were detected. For PCR amplification, the following thermal cycling conditions were adopted: initial denaturation at $94^{\circ} \mathrm{C}$ for $3 \mathrm{~min}$, followed by 30 cycles $\left(94^{\circ} \mathrm{C}\right.$ for $1 \mathrm{~min}, 58-62^{\circ} \mathrm{C}$ for $1 \mathrm{~min}$ and $72^{\circ} \mathrm{C}$ for $1 \mathrm{~min}$ ), and a final extension step of $8 \mathrm{~min}$ at $72^{\circ} \mathrm{C}$. PCR products were separated by electrophoresis (at $100 \mathrm{~V}$ through a $1 \%$ agarose gel in $0.5 \times \mathrm{TBE}$ running buffer), stained with ethidium bromide and observed under ultraviolet light. Identity of all PCR products was confirmed by DNA sequencing (Beijing Genomics Institute, BGI).

\section{Genotyping of isolates}

For determination of genetic relatedness of the isolates, enterobacterial repetitive intergenic consensusPCR (ERIC-PCR) was performed with primer ERIC2 (5'-AAGTAAGTGACTGGGGTGAGCG-3') (Bahador A et al. 2015) to amplify the conserved sequences of bacterial strains, by using the following thermal cycling conditions: initial denaturation at $94^{\circ} \mathrm{C}$ for $5 \mathrm{~min}, 4$ cycles $\left(94^{\circ} \mathrm{C}\right.$ for $1 \mathrm{~min}, 26^{\circ} \mathrm{C}$ for $1 \mathrm{~min}, 72^{\circ} \mathrm{C}$ for $\left.1 \mathrm{~min}\right)$, then $40 \mathrm{cycles}\left(94^{\circ} \mathrm{C}\right.$ for $30 \mathrm{sec}, 40^{\circ} \mathrm{C}$ for $30 \mathrm{sec}$ and $72^{\circ} \mathrm{C}$ for $1 \mathrm{~min}$ ), and extension at $72^{\circ} \mathrm{C}$ for $5 \mathrm{~min}$. To resolve the PCR products, each PCR product was analyzed by electrophoresis in a $1.5 \%$ agarose gel stained with ethidium bromide. Results for ERIC-PCR banding patterns were appraised by the software Quantity One (version 4.6.2) and scored as absent (0) or present (1) to construct a dendrogram according to the the unweighted pair group (UPGMA) method, using the software NTSYS-pc (version 2.10e). Isolates with more than $90 \%$ similarity were considered as belonging to the same cluster.

\section{Statistics analysis}

Statistical analysis on the correlation between different resistance genes was performed by rank-order correlation with SPSS 19.0 software. The difference in AMR rates was analyzed by Chi-squared test. Statistical significance was determined at $p$ value $<0.05$.

\section{Results}

\section{Isolate characteristics and resistance rates}

As shown in Figure 1, resistance rates of total $A$. baumannii against commonly used antibiotics (notably imipenem, gentamycin and tobramycin) had been persistently high( $>70 \%)$ at the ICU in recent years, especially in a spiral upward trend to the antibiotics such as cefepime (FEP), imipenem (IPM), piperacillin/tazobactam (TZP), gentamycin (GEN) and ciprofloxacin (CIP). LVX was the only suvival with a resistance rate under $70.00 \%$. In this study, a total of 95 non-duplicative $A$. baumannii strains were isolated from ICU patients. Strains from male patients evidently outnumbered those from females at a ratio of $65(68.42 \%)$ to $30(31.58 \%)$. Affected patients had a mean age of $61.93 \pm 1.87$ years (range of 7 to 89 years old). The major isolation sites were sputum $(n=91)$, drain $(n=2)$ and stool $(n=2)$. As shown in Table 2, AST results suggested that all isolates could be qualified as multidrug resistant (MDR) $A$. baumannii, which showed high rates of extensive resistance to 8 antibiotics tested including cefepime (FEP), ceftriaxone (CRO), imipenem (IPM), gentamycin (GEN), tobramycin (TOB), ciprofloxacin (CIP), trimethoprim/sulfamethoxazole (SXT), piperacillin/tazobactam (TZP) at 93.68\%, 92.63\%, 93.68\%, 
$89.47 \%, 86.32 \%, 94.74 \%, 81.05 \%$ and $83.16 \%$, respectively. Importantly, despite a full resistance rate of below $55.00 \%$, levofloxacin (LVX) might not be deemed any more effective than the abovementioned agents against $A$. baumannii, as it had a notable rate of intermediate-level resistance (37.90\%). The susceptibility rates of the isolates toward all tested antibiotics were below $20.00 \%$.

\section{Genotypic patterns in ERIC-PCR analysis}

ERIC-PCR was used to compare the genetic relatedness among the $A$. baumannii isolates. All PCR banding patterns ranging from $550 \mathrm{bp}$ to $2000 \mathrm{bp}$ were analyzed by the NTSYS software to construct a dendrogram, as shown in Figure 2. In general, the analyzed $A$. baumannii strains could be organized into 10 distinct clusters, where 86 (or $90.53 \%$ ) of the isolates belonged to the major Cluster $A$, while the remaining 9 isolates exhibited substantially different banding patterns, additionally designated as Clusters B, C, D, F, G, H, J and K. In longitudinal analysis, strains belonging to Cluster A were detectable throughout the study period in 2015 , indicating that members of this cluster correspond to major epidemic clones.

\section{Determination of antimicrobial resistance genes}

Analysis on AMR genes suggests that the A. baumannii isolates included in this study had high carriage rates for some specific AMR genes. Among the 95 strains, 87 (91.58\%) were tested positive for the ESBL encoding gene $b / a_{T E M-1}$, while all strains contained the cephalosporinase gene $b / a_{A D C}$. In terms of detection of carbapenemase genes, 88 strains $(92.63 \%)$ were found to harbour the bla OXA23 gene, while the bla $a_{O X A 51}$ gene was universally detected in all isolates, consistent with the premise that it is an intrinsic resistance determinant in $A$. baumannii. Gene $\operatorname{armA}$, a member of $16 \mathrm{~S}$ rRNA methylases, was detected in 84 isolates (88.42\%), while the most prevalent AMEs encoding gene aph ( $\left.3^{\prime}\right)$-I was found in 82 isolates (86.32\%). In comparison, 29 (30.53\%) and 25 (26.32\%) of the isolates harboured the ant (3")-Iand aac $\left(6^{\prime}\right)-I b$ genes, respectively. In further analysis, the genes $b / a_{S H V}, b / a_{I M P}, b / a_{V I M-2}, b / a_{N D M-1}, b / a_{O X A 24}$ and bla $a_{O X 58}$ were undetected in any of the $A$. baumannii strains.

Through genotyping and detection of resistance genes, we classified the 95 isolates of A. baumannii in this study, as shown in Table 3. Cluster A could be categorized into 9 subtypes on the basis of different AMR gene combinations. The most prevalent subtype in Cluster A was subtype Ai, comprising 55 (63.95\%) isolates expressing the genes bla ${ }_{O X A 23}, b / a_{O X A 51}, b / a_{T E M-1}, b / a_{A D C}$, armA and aph (3')-l. Among subtype $\mathrm{Ai}$ isolates, 38 (44.19\%) were insensitive to all of the antibiotics tested. Twenty two $(25.58 \%)$ isolates in group Aii harboured 8 different genes, namely, bla $a_{O X 23}, b / a_{O X A 51}, b / a_{T E M-1}, b / a_{A D C}$ armA, aph $\left(3^{\prime}\right)-I$, aac $\left(6^{\prime}\right)-I b$, and ant ( $\left.3^{\prime \prime}\right)-I$. The 20 isolates in subtype Aii were also insensitive to all antibiotics tested. Gene bla $a_{T E M-1}$ was absent in group Aix which, however, was also found to be insensitive to cefepime and ceftriaxone. The aminoglycoside resistance genes aph (3')-I and ant (3")-I were only detected in subtypes Aviii and Aix, but surprisingly these were susceptible to gentamycin and tobramycin. The rest of the cluster showed various combinations of AMR genes, presumably giving rise to different resistance patterns. Members of Clusters $\mathrm{C}, \mathrm{E}, \mathrm{J}$ and $\mathrm{K}$ also expressed the genes $b / a_{O X A 51}$ and $b / a_{A D C}$ and showed an 
appreciably higher level of susceptibility than isolates in other clusters. Notably, despite the absence of carbapenemase gene bla OXA23 in Cluster $\mathrm{F}$, its members showed insensitivity to imipenem, in comparison with other clusters.

\section{Discussion}

ERIC-PCR, a genotyping method premised on amplification of conserved regions of genomic DNA, has the advantage of facile instrumentation and reliability comparable to Pulsed Field Gel Electrophoresis (PFGE). It has been proven useful for determining genomic relationship across strains with heterogeneous backgrounds (Cartelle Gestal $M$ et al. 2016; Ece $G$ et al. 2015). In the present study, a dendrogram based on ERIC-PCR results identifies 10 distinct clusters (A, B, C, D, E, F, G, H, J, K). Notably, $90.52 \%(86 / 95)$ of the strains were classified into Cluster $A$, the principal cluster. Indeed, throughout the study period, isolates belonging to Cluster A were detected each month. In terms of resistance phenotype, strains in Cluster A were consistently more insensitive to all tested antibiotics than were strains in other clusters. This suggested that a single dominant clone of MDR-A. baumannii prevailed in the ICU in 2015 (Jan. to Dec.). By using ERIC-PCR as a genotyping method, Ning and coworkers reported carbapenemresistant clones of $A$. baumannii spreading at an ICU in western China (Ning NZ et al. 2017). Chen and coworkers also described a major epidemic strain spreading at different hospital units in Hunan province of southern China (Chen D et al.2016). In our study, the spreading of $A$. baumannii strains in the ICU lasted for a substantial period and their resistance rates to antibiotics were extremely high. We found that among the 9 subtypes of strains within Cluster A, the most frequent type of AMR gene combination was

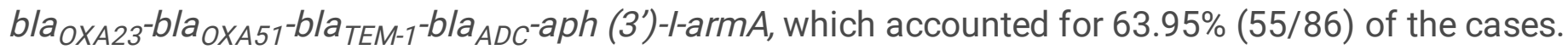
Strains harbouring this gene combination could be routinely isolated throughout the study period, suggesting the existence of entrenched extrinsic factors favoring their spread. Cross-transmission and contamination within the ward environment might underpin this process, which calls for greater awareness for monitoring and timely disinfection of the ward environment.

In our study, we found that multidrug-resistant Acinetobacter baumannii (MDRAB) strains simultaneously carrying the bla $\mathrm{OXA23}_{3}$ gene and multiple aminoglycoside resistance genes are apparently spreading in southern China. The carriage of $b a_{O X A 23}$ carbapenemases in $A$. baumannii has been documented worldwide and bla ${ }_{\mathrm{OXA23}}$ was one of the most prevalent carbapenemase genes detected in Chinese hospitals (Ruan Z et al. 2013; Shoja S et al. 2017). While the prevalence of A. baumannii co-expressing aminoglycoside resistance genes and carbapenemases genes have been reported in eastern China (Wang $Y$ et al. 2016), to the best of our knowledge, there have been no studies on the epidemicity of $A$. baumannii co-carrying AMR genes against aminoglycosides and carbapenems in southern China.

A high percentage $(95.80 \% ; n=91)$ of the total strains in our study originated from sputum, which is similar to findings in a recent epidemiological study covering 10 tertiary-care teaching hospitals in northern China (Jiang M et al. 2016).It has been suggested that most of the HAls took the form of 
ventilator-associated pneumonia caused by mechanical ventilation, which occasionally even gave rise to outbreaks in ICUs by cross-infections (Munoz-Price LS and Weinstein RA. 2008; Peng H et al. 2015).

A. baumannii resistance rates to antibiotics seem to be increasing across the years. That high resistance to almost all antibiotics tested in this study indicated doctors were facing embarrassed situations on selecting antibiotic for infections caused by MDRAB in ICU. Since current treatment options for MDRAB were extremely limited, colistin is often considered as the last line of therapy for it (Gounden et al. 2009), although colistin-resistant $A$. baumannii had been reported (Al-Agamy MH et al. 2014).

The ESBL-producing genes $b / a_{T E M-1}$ and $b / a_{A D C}$ identified in this study belong to Ambler class $\mathrm{A}$ and class $C$ on $\beta$-lactamase coding genes, respectively. The gene $b l a_{A D C}$ along with the chromosomally located gene bla OXA51 $_{1}$ were consistently detected in A. baumannii, suggesting that they may be useful as signature genes for species confirmation. With the absence of $b / a_{T E M-1}$ gene, strains in Clusters $\mathrm{C}, \mathrm{D}, \mathrm{E}, \mathrm{H}$, $\mathrm{J}$ and $\mathrm{K}$ were susceptible to FEP compared to those in Cluster $\mathrm{F}$ and $\mathrm{G}$, but were still insensitive to $\mathrm{CRO}$. In view of the above observations, we speculated that strains with bla $a_{T E M-1}$ gene may gain advantage in FEP resistance. It is noteworthy that $b / a_{T E M-1}$ gene was the most prevalent ESBL gene in the present study, which differs from a previous study, where bla ${ }_{C T X-M}$ was reported to be the predominant ESBL gene (Mahamat A et al. 2016).

Conventionally, aminoglycosides are used in combination with $\beta$-lactams in anti-infective regimens to treat $A$. baumannii infections (Wang $Y$ et al. 2016). However, aminoglycoside resistance $A$. baumannii has been reported with increasing frequency in China in recent years (Gao L et al. 2017; Jiang M et al. 2014; Lin T et al. 2015). The resistance rates for GEN and TOB in this study were $89.47 \%$ and $86.32 \%$, respectively (Table 2). A study reported by Wen et al. (2014) showed high resistance rates in Jiangsu province, eastern China. Aminoglycoside modify enzymes (AMEs) and 16S rRNA methylase have been attributed as a molecular basis for aminoglycoside resistance. In the present study, 3 different AMEs and one 16S rRNA methylase genes were detected. The most prevalent of the AMEs was aph( $\left.3^{\prime}\right)-1(86.32 \%)$, followed by ant( $\left(3^{\prime \prime}\right)-I(30.53 \%)$, with $84(88.42 \%)$ of the strains carrying armA. In a study on A. baumannii from Jiangsu province, China the most prevalent AMEs were identified as $\operatorname{aac}\left(3^{\prime}\right)-I$ and $\operatorname{aac}\left(6^{\prime}\right)-I b$ (Wen JT et al. 2014). We noted that $A$. baumannii from different parts of China feature different aminoglycoside resistance genes (Wang $\mathrm{H}$ et al. 2017). For example, the most representative aminoglycoside resistance gene combination in the present study was armA-aph(3')-I(58.95\%). It is known that AMEs genes could be detected in both aminoglycoside-resistant and susceptible strains (as in Cluster $\mathrm{H}$ ). Gene products of AMEs are reportedly responsible for moderate-level resistance, whereas 16S rRNA methylase has been attributed to high-level aminoglycosides resistance (Wang Y et al. 2016). Interestingly, strains in Cluster B exhibited susceptibility to both GEN and TOB with only armA gene being detected. Some possible reasons include that $16 \mathrm{~S}$ rRNA methylase may not be acting alone and that some uncharacterized mechanisms modulate armA activity.

In addition, high levels of aminoglycoside resistance co-occurring with carbapenems resistance have been reported in epidemic clones of $A$. baumannii from western China (Lin T et al. 2015). The imipenem 
resistance rates of $A$. baumannii were extremely high in China and numerous studies have raised concerns over the emergence and spread of imipenem-resistant $A$. baumannii in hospitals (Neves FC et al. 2016). Resistance rates for imipenem reported in different Chinese ranged from $58 \%$ to $100 \%$ (Jiang M et al. 2016; Zong Z et al. 2008; Ji S et al. 2014; Wu W et al. 2015) \and this alarming trend seems to continue to rise unabated each year. For $A$. baumannii strains included in this study, the resistance rate for imipenem was $93.68 \%$. Our current results suggested that efficacy of carbapenems as treatment for MDR-AB infections seemed to be fast diminishing, especially in ICU contexts. Ruan and coworkers found that a carbapenem-resistant status of $A$. baumannii isolates was predictive of high resistance rates to commonly used antibiotics. In terms of mechanisms, carriage of metallo- $\beta$-lactamases (MBLs) and carbapenem-hydrolyzing class $\mathrm{D} \beta$-lactamases (CHDLs) has been attributed to carbapenem resistance (Ruan Z et al. 2013). A growing body of literature documents bla ${ }_{O X A 23}$ as a predominant carbapenemase genotype among epidemic clones in China (Chen Y et al. 2017; Rapee Thummeepak et al. 2016) and outbreaks caused by bla $\mathrm{OXA23}_{2}$ producing $A$. baumannii paralleled those occurring worldwide (Neves FC et al. 2016; Hammoudi D et al. 2015;Novovic K et al. 2015;Koh TH et al. 2007;Martins AF et al. 2009). In this present study, we found that 88 of the $A$. baumannii strains $(92.63 \%)$ harboured a bla OXA23 $_{2}$ gene, suggestive of a level of prevalence seen in other parts of China (Ana Kovacic et al. 2017). In contrast, alternative AMR genes supporting the developing of MDR phenotypes such as $b / a_{O X A 24}, b / a_{O X A 5{ }^{\prime}}, b / a_{I M P}$,

$b / a_{V I M-2}, b / a_{N D M-1}$ genes were detected. Collectively, we proposed that the presence of bla $a_{O X A 23}$ gene could be a cardinal molecular determinant of carbapenem resistance in our study.

\section{Conclusion}

In this study, we described the resistance traits and genetic relatedness of MDR A. baumannii strains with high resistance that prevailed at the ICU of a teaching tertiary hospital in the Chaoshan area of Guangdong province, a populous yet epidemiologically overlooked region in southern China. Extreme resistance to carbapenem and aminoglycoside classes of antibiotics including imipenem and gentamycin/tobramycin may be associated with the carriage of bla ${ }_{O X A 23}$ and AMEs genes as determined in PCR assays. A single Cluster A of epidemic clones seemed to dominate the spread of MDR A. baummannii at the ICU. Surveillance work in this study represents a first step towards a better understanding of MDR A. baumannii as a causative agent in ICUs, which calls for greater attention to continued monitoring and rational use of antibiotics.

\section{References}

1. Al-Agamy MH, Khalaf NG, Tawfick MM, Shibl AM, El Kholy A (2014) Molecular characterization of carbapenem-insensitive Acinetobacter baumannii in Egypt. Int $\mathrm{J}$ Infect Dis 22:49-54. https://doi.org/10.1016/j.ijid.2013.12.004

2. Ana Kovacic MSerugaMSvjetlana, Dekic M, Tonkic A, Novak Z, Rubic et al (2017) Transmission and survival of carbapenem resistant Acinetobacter baumannii outside hospital setting. Int Microbiol 20(4):165-169. https://doi.org/10.2436/20.1501.01.299 
3. Bahador A, Raoofian R, Pourakbari B, Taheri M, Hashemizadeh Z, Hashemi FB (2015) Genotypic and Antimicrobial Susceptibility of Carbapenem-resistant Acinetobacter baumannii: Analysis of is Aba Elements and bla OXA-23-like Genes Including a New Variant. Front Microbiol 6:1249. https://doi.org/10.3389/fmicb.2015.01249

4. Behdad R, Pargol M, Mirzaie A, Karizi SZ, Noorbazargan H, Akbarzadeh I (2020) Efflux pump inhibitory activity of biologically synthesized silver nanoparticles against multidrug-resistant Acinetobacter baumannii clinical isolates. J Basic Microbiol 60:494-507. https://doi.org/10.1002/jobm.201900712

5. Carmen GomezArrebola C, Solano I Lasa (2021) Regulation of gene expression by nonphosphorylated response regulators. International Microbiology Published online: 13 May 2021. https://doi.org/10.1007/s10123-021-00180-2

6. Cartelle Gestal M, Zurita J, Gualpa G, Gonzalez C, Paz YMA (2016) Early detection and control of an Acinetobacter baumannii multi-resistant outbreak in a hospital in Quito, Ecuador. J Infect Dev Ctries 10(12):1294-1298. https://doi.org/10.3855/jidc.7544

7. Chen D, Xie J, Chen H, Yang Y, Zhan Z, Liang L et al (2016) Infection in Southern Chinese Patients with Systemic Lupus Erythematosus: Spectrum, Drug Resistance, Outcomes, and Risk Factors. J Rheumatol 43(9):1650-1656. https://doi.org/10.3899/jrheum.151523

8. Chen Y, Gao J, Zhang H, Ying C (2017) Spread of the blaOXA-23-Containing Tn2008 in CarbapenemResistant Acinetobacter baumannii Isolates Grouped in CC92 from China. Front Microbiol 8:163. https://doi.org/10.3389/fmicb.2017.00163

9. del Mar Tomas M, Cartelle M, Pertega S, Beceiro A, Llinares P, Canle D et al (2005) Hospital outbreak caused by a carbapenem-resistant strain of Acinetobacter baumannii: patient prognosis and riskfactors for colonisation and infection. Clin Microbiol Infect 11(7):540-546. https://doi.org/10.1111/j.1469-0691.2005.01184.x

10. Ece G, Erac B, Yurday Cetin H, Ece C, Baysak A (2015) Antimicrobial Susceptibility and Clonal Relation Between Acinetobacter baumannii Strains at a Tertiary Care Center in Turkey. Jundishapur J Microbiol 8(2):e15612. https://doi.org/10.5812/jjm.15612

11. Freire MP, de Oliveira Garcia D, Garcia CP, Campagnari Bueno MF, Camargo CH, Kono Magri ASG et al (2016) Bloodstream infection caused by extensively drug-resistant Acinetobacter baumannii in cancer patients: high mortality associated with delayed treatment rather than with the degree of neutropenia. Clin Microbiol Infect 22(4):352-358. https://doi.org/10.1016/j.cmi.2015.12.010

12. Gao L, Lyu Y, Li Y (2017) Trends in Drug Resistance of Acinetobacter baumannii over a 10-year Period: Nationwide Data from the China Surveillance of Antimicrobial Resistance Program. Chin Med J 130(6):659-664. https://doi.org/10.4103/0366-6999.201601

13. Hammoudi D, Moubareck CA, Hakime N, Houmani M, Barakat A, Najjar Z et al (2015) Spread of imipenem-resistant Acinetobacter baumannii co-expressing OXA-23 and GES-11 carbapenemases in Lebanon. Int J Infect Dis 36:56-61. https://doi.org/10.1016/j.ijid.2015.05.015 
14. He C, Xie Y, Fan H, Kang M, Tao C, Zhang R et al (2011) Spread of imipenem-resistant Acinetobacter baumannii of European clone II in Western China. Int J Antimicrob Agents 38(3):257-260. https://doi.org/10.1016/j.ijantimicag.2011.04.015

15. Jiang M, Liu L, Ma Y, Zhang Z, Li N, Zhang F et al (2016) Molecular Epidemiology of Multi-Drug Resistant Acinetobacter baumannii Isolated in Shandong, China. Front Microbiol 7:1687. https://doi.org/10.3389/fmicb.2016.01687

16. Jiang $M$, Zhang Z, Zhao S (2014) Epidemiological characteristics and drug resistance analysis of multidrug-resistant Acinetobacter baumannii in a China hospital at a certain time. Polish journal of microbiology 63(3):275-281

17. Ji S, Chen Y, Ruan Z, Fu Y, Ji J, Fu Y et al (2014) Prevalence of carbapenem-hydrolyzing class D betalactamase genes in Acinetobacter spp. isolates in China. Eur J Clin Microbiol Infect Dis 33(6):989997. https://doi.org/10.1007/s10096-013-2037-z

18. Koh TH, Sng LH, Wang GC, Hsu LY, Zhao Y (2007) IMP-4 and OXA beta-lactamases in Acinetobacter baumannii from Singapore. J Antimicrob Chemother 59(4):627-632. https://doi.org/10.1093/jac/dkl544

19. Lin T, Tang CG, Li QH, Ji J, Ge HY, Zhang XY et al (2015) Identification of aac(2')-I type b aminoglycoside-modifying enzyme genes in resistant Acinetobacter baumannii. Genet Mol Res 14(1):1828-1835. https://doi.org/10.4238/2015.March.13.11

20. Li Y, Cao X, Ge H, Jiang Y, Zhou H, Zheng W (2018) Targeted surveillance of nosocomial infection in intensive care units of 176 hospitals in Jiangsu province, China. J Hosp Infect 99(1):36-41. https://doi.org/10.1016/j.jhin.2017.10.009

21. Li Y, Pan C, Zhao Z, Zhao Z, Chen H, Lu W (2013) Effects of a combination of amlodipine and imipenem on 42 clinical isolates of Acinetobacter baumannii obtained from a teaching hospital in Guangzhou, China. BMC Infect Dis 13:548. https://doi.org/10.1186/1471-2334-13-548

22. Mahamat A, Bertrand X, Moreau B, Hommel D, Couppie P, Simonnet C et al (2016) Clinical epidemiology and resistance mechanisms of carbapenem-resistant Acinetobacter baumannii, French Guiana, 2008-2014. Int J Antimicrob Agents 48(1):51-55. https://doi.org/10.1016/j.ijantimicag.2016.03.006

23. Mariana Bitrian CM, Solari, Rodrigo H, González, Clara B, Nudel (2012) Identification of virulence markers in clinically relevant strains of Acinetobacter genospecies. Int Microbiol 15:79-88. https://doi.org/10.2436/20.1501.01.161

24. Martins AF, Kuchenbecker R, Sukiennik T, Boff R, Reiter KC, Lutz L et al (2009) Carbapenem-resistant Acinetobacter baumannii producing the OXA-23 enzyme: dissemination in Southern Brazil. Infection 37(5):474-476. https://doi.org/10.1007/s15010-009-9003-9

25. Molter G, Seifert H, Mandraka F, Kasper G, Weidmann B, Hornei B et al (2016) Outbreak of carbapenem-resistant Acinetobacter baumannii in the intensive care unit: a multi-level strategic management approach. J Hosp Infect 92(2):194-198. https://doi.org/10.1016/j.jhin.2015.11.007 
26. Munoz-Price LS, Weinstein RA (2008) Acinetobacter infection. N Engl J Med 358(12):1271-1281. https://doi.org/10.1056/NEJMra070741

27. Neves FC, Clemente WT, Lincopan N, Paiao ID, Neves PR, Romanelli RM et al (2016) Clinical and microbiological characteristics of OXA-23- and OXA-143-producing Acinetobacter baumannii in ICU patients at a teaching hospital, Brazil. Braz J Infect Dis 20(6):556-563.

https://doi.org/10.1016/j.bjid.2016.08.004

28. Ning NZ, Liu X, Bao CM, Chen SM, Cui EB, Zhang JL et al (2017) Molecular epidemiology of bla OXA23 -producing carbapenem-resistant Acinetobacter baumannii in a single institution over a 65-month period in north China. BMC Infect Dis 17(1):14. https://doi.org/10.1186/s12879-016-2110-1

29. Novovic K, Mihajlovic S, Vasiljevic Z, Filipic B, Begovic J, Jovcic B (2015) Carbapenem-resistant Acinetobacter baumannii from Serbia: revision of CarO classification. PLoS One 10(3):e0122793. https://doi.org/10.1371/journal.pone.0122793

30. Peng H, Tao XB, Li Y, Hu Q, Qian LH, Wu Q et al (2015) Health care-associated infections surveillance in an intensive care unit of a university hospital in China, 2010-2014: Findings of International Nosocomial Infection Control Consortium. Am J Infect Control 43(12):e83-e85. https://doi.org/10.1016/j.ajic.2015.07.023

31. Rapee Thummeepak P, Kongthai U, Leungtongkam S, Sitthisak (2016) Distribution of virulence genes involved in biofilm formation in multi-drug resistant Acinetobacter baumannii clinical isolates. Int Microbiol 19:121-129. https://doi.org/10.2436/20.1501.01.270

32. Ruan Z, Chen Y, Jiang Y, Zhou H, Zhou Z, Fu Y et al (2013) Wide distribution of CC92 carbapenemresistant and OXA-23-producing Acinetobacter baumannii in multiple provinces of China. Int J Antimicrob Agents 42(4):322-328. https://doi.org/10.1016/j.ijantimicag.2013.06.019

33. Shamsizadeh Z, Nikaeen M, Nasr Esfahani B, Mirhoseini SH, Hatamzadeh M, Hassanzadeh A (2017) Detection of antibiotic resistant Acinetobacter baumannii in various hospital environments: potential sources for transmission of Acinetobacter infections. Environ Health Prev Med 22(1):44. https://doi.org/10.1186/s12199-017-0653-4

34. Shimose LA, Masuda E, Sfeir M, Berbel Caban A, Bueno MX, dePascale D et al (2016) CarbapenemResistant Acinetobacter baumannii: Concomitant Contamination of Air and Environmental Surfaces. Infect Control Hosp Epidemiol 37(7):777-781. https://doi.org/10.1017/ice.2016.69

35. Shoja S, Moosavian M, Rostami S, Farahani A, Peymani A, Ahmadi K et al (2017) Dissemination of carbapenem-resistant Acinetobacter baumannii in patients with burn injuries. J Chin Med Assoc 80(4):245-252. https://doi.org/10.1016/j.jcma.2016.10.013

36. Wang H, Wang J, Yu P, Ge P, Jiang Y, Xu R et al (2017) Identification of antibiotic resistance genes in the multidrug-resistant Acinetobacter baumannii strain, MDR-SHH02, using whole-genome sequencing. Int J Mol Med 39(2):364-372. https://doi.org/10.3892/ijmm.2016.2844

37. Wang Y, Shen M, Yang J, Dai M, Chang Y, Zhang C et al (2016) Prevalence of carbapenemases among high-level aminoglycoside-resistant Acinetobacter baumannii isolates in a university hospital in China. Exp Ther Med 12(6):3642-3652. https://doi.org/10.3892/etm.2016.3828 
38. Wen JT, Zhou Y, Yang L, Xu Y (2014) Multidrug-resistant genes of aminoglycoside-modifying enzymes and 16S rRNA methylases in Acinetobacter baumannii strains. Genet Mol Res 13(2):38423849. https://doi.org/10.4238/2014.May.16.9

39. Wu W, He Y, Lu J, Lu Y, Wu J, Liu Y (2015) Transition of blaOXA-58-like to blaOXA-23-like in Acinetobacter baumannii Clinical Isolates in Southern China: An 8-Year Study. PLoS One 10(9):e0137174. https://doi.org/10.1371/journal.pone.0137174

40. Zhou K, Tang X, Wang L, Guo Z, Xiao S, Wang Q et al (2018) An Emerging Clone (ST457) of Acinetobacter baumannii Clonal Complex 92 With Enhanced Virulence and Increasing Endemicity in South China. Clinical infectious diseases: an official publication of the Infectious Diseases Society of America 67(suppl_2):S179-Ss188. https://doi.org/10.1093/cid/ciy691

41. Zhou Y, Wu X, Zhang X, Hu Y, Yang X, Yang Z et al (2015) Genetic Characterization of ST195 and ST365 Carbapenem-Resistant Acinetobacter baumannii Harboring blaOXA-23 in Guangzhou, China. Microb Drug Resist 21(4):386-390. https://doi.org/10.1089/mdr.2014.0183

42. Zong Z, Lu X, Valenzuela JK, Partridge SR, Iredell J (2008) An outbreak of carbapenem-resistant Acinetobacter baumannii producing OXA-23 carbapenemase in western China. Int J Antimicrob Agents 31(1):50-54. https://doi.org/10.1016/j.ijantimicag.2007.08.019

\section{Tables}

Table 1. Primer sequences used in this study for detecting resistance genes. 


\begin{tabular}{|c|c|c|c|}
\hline Target gene & Sequence $5^{\prime} \rightarrow 3^{\prime}$ & Annealing temp. $\left({ }^{\circ} \mathrm{C}\right)$ & Amplicon size (bp) \\
\hline \multirow[t]{2}{*}{$b a_{T E M-1}$} & ACCCAGAAACGCTGGTGAAA & 57 & 724 \\
\hline & TGACTCCCCGTCGTGTAGAT & & \\
\hline \multirow[t]{2}{*}{$b_{\text {shv }}$} & TTATCTCCСTGTTAGCCACC & 55 & 795 \\
\hline & GATTTGCTGATTTCGCTCGG & & \\
\hline \multirow[t]{2}{*}{$b / a_{I M P}$} & AATTGAGAAGCTTGAAGAAGGCG & 56 & 621 \\
\hline & TTAACAGCCTGCTCCCATGT & & \\
\hline \multirow[t]{2}{*}{ bla $_{V I M-2}$} & AGTCTCCACGCACTTTCAT & 57 & 505 \\
\hline & CACAACCACCATAGAGCACA & & \\
\hline \multirow[t]{2}{*}{$b l a_{N D M-1}$} & GGTTTGGCGATCTGGTTTTC & 55 & 621 \\
\hline & CGGAATGGCTCATCACGATC & & \\
\hline \multirow[t]{2}{*}{ bla $_{A D C}$} & TAAACACCACATATGTTCCG & 58 & 663 \\
\hline & АCTTACTTCAACTCGCGACG & & \\
\hline \multirow[t]{2}{*}{ bla $0 \times A 51$} & TCCAAATCACAGCGCTTCAA & 57 & 703 \\
\hline & TCGAACAGAGCTAGGTATTCCTTT & & \\
\hline \multirow[t]{2}{*}{ bla ${ }_{O X A 23}$} & TTTCTGGTTGTACGGTTCAGCA & 57 & 646 \\
\hline & AACCAGCCCACTTGTGGTTTT & & \\
\hline \multirow[t]{2}{*}{ bla } & GTTTCTCTCAGTGCATGTTCATCT & 55 & 664 \\
\hline & CCCAACCAGTCAACCAACCT & & \\
\hline \multirow[t]{2}{*}{ bla ${ }_{O X A 58}$} & CCAATCGGCTTTTTCTTCAGCA & 56 & 837 \\
\hline & TCATCACCAGCTTTCATTTGCAT & & \\
\hline \multirow[t]{2}{*}{$\operatorname{aac}\left(6^{\prime}\right)-1 b$} & TTGCGATGCTCTATGAGTGGCTA & 57 & 482 \\
\hline & CTCGAATGCCTGGCGTGTTT & & \\
\hline \multirow[t]{2}{*}{$\operatorname{ant}\left(3^{\prime \prime}\right)-I$} & GCCATACAGCGATATTGATTTG & 58 & 306 \\
\hline & AAGGCAACGCTATGTTCTCTTG & & \\
\hline \multirow[t]{2}{*}{$\operatorname{aph}\left(3^{\prime}\right)-I$} & CGTTGCCAATGATGTTACAGAT & 58 & 333 \\
\hline & TTACGCTCGTCATCAAAATCAC & & \\
\hline $\operatorname{armA}$ & TGAAAAGGTTGTTTCCATTTCTGA & 57 & 669 \\
\hline
\end{tabular}


Table 2 Antimicrobial susceptibility profiles of $A$. baumannii isolates.

\begin{tabular}{|c|c|c|c|c|c|c|c|c|c|}
\hline \multirow[t]{2}{*}{ Antibiotics } & \multicolumn{2}{|c|}{ Resistance } & \multicolumn{2}{|c|}{ Intermediate } & \multicolumn{2}{|c|}{ Susceptible } & \multirow[t]{2}{*}{ MIC range } & \multirow[t]{2}{*}{$\mathrm{MIC}_{50}$} & \multirow[t]{2}{*}{$\mathrm{MIC}_{90}$} \\
\hline & $n$ & Rate (\%) & $n$ & Rate (\%) & $n$ & Rate (\%) & & & \\
\hline FEP & 89 & 93.68 & 0 & 0.00 & 6 & 6.32 & $1-64$ & 64 & 64 \\
\hline CRO & 88 & 92.63 & 7 & 7.37 & 0 & 0.00 & $1-64$ & 64 & 64 \\
\hline IPM & 89 & 93.68 & 0 & 0.00 & 6 & 6.32 & $1-16$ & 16 & 16 \\
\hline GEN & 85 & 89.47 & 2 & 2.11 & 8 & 8.42 & $1-16$ & 16 & 16 \\
\hline TOB & 82 & 86.32 & 0 & 0.00 & 13 & 13.68 & $1-16$ & 16 & 16 \\
\hline LVX & 51 & 53.68 & 36 & 37.90 & 8 & 8.42 & $0.25-8$ & 4 & 8 \\
\hline CIP & 90 & 94.74 & 0 & 0.00 & 5 & 5.26 & $0.25-4$ & 4 & 4 \\
\hline SXT & 77 & 81.05 & 0 & 0.00 & 18 & 18.95 & $1-16$ & 16 & 16 \\
\hline TZP & 79 & 83.16 & 4 & 4.21 & 12 & 12.63 & $4-28$ & 128 & 128 \\
\hline
\end{tabular}

Table 3. Classification of MDR A. baumannii isolates based upon ERIC-PCR and genotypic profiles. 


\begin{tabular}{|c|c|c|c|c|}
\hline Cluster & $n(\%)$ & $\begin{array}{l}\text { Subtype } \\
\text { (n) }\end{array}$ & Resistance genes $^{a}$ & $\begin{array}{l}\text { Resistance patterns } \\
(\mathrm{R}+1)^{b}\end{array}$ \\
\hline \multirow[t]{15}{*}{ A } & \multirow[t]{15}{*}{$\begin{array}{l}86 \\
(90.35)\end{array}$} & \multirow[t]{5}{*}{$\mathrm{Ai}(55)$} & \multirow[t]{5}{*}{$\begin{array}{l}\text { bla }_{O X A 51}, b^{\prime} a_{A D C}, \text { bla } \\
\text { armA }, \text { aph }\left(3^{\prime}\right)-1\end{array}$} & $\begin{array}{l}\text { FEP, CRO, IPM, GEN, TOB, } \\
\text { LVX, CIP, SXT (40) }\end{array}$ \\
\hline & & & & $\begin{array}{l}\text { FEP, CRO, IPM, GEN, TOB, } \\
\text { LVX, CIP, SXT (6) }\end{array}$ \\
\hline & & & & $\begin{array}{l}\text { FEP, CRO, IPM, GEN, TOB, } \\
\text { LVX, CIP (5) }\end{array}$ \\
\hline & & & & $\begin{array}{l}\text { FEP, CRO, IPM, GEN, TOB, } \\
\text { LVX, CIP (4) }\end{array}$ \\
\hline & & & & $\begin{array}{l}\text { FEP, CRO, IPM, GEN, TOB, } \\
\text { CIP ( } 1)\end{array}$ \\
\hline & & \multirow[t]{3}{*}{ Aii (22) } & \multirow[t]{3}{*}{$\begin{array}{l}\text { bla }_{O X A 51}, b a_{A D C}, \text { bla } \\
\operatorname{armA}, \operatorname{aph}\left(3^{\prime}\right)-1, \operatorname{aac}\left(6^{\prime}\right)-1 b, \operatorname{ant}\left(3^{\prime \prime}\right)-1\end{array}$} & $\begin{array}{l}\text { FEP, CRO, IPM, GEN, TOB, } \\
\text { LVX, CIP, SXT (20) }\end{array}$ \\
\hline & & & & $\begin{array}{l}\text { FEP, CRO, IPM, GEN, TOB, } \\
\text { LVX, CIP (1) }\end{array}$ \\
\hline & & & & $\begin{array}{l}\text { FEP, CRO, IPM, GEN, TOB, } \\
\text { LVX, CIP (1) }\end{array}$ \\
\hline & & Aiii (2) & 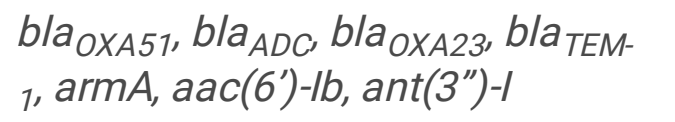 & $\begin{array}{l}\text { FEP, CRO, IPM, GEN, TOB, } \\
\text { LVX, CIP, SXT }\end{array}$ \\
\hline & & Aiv (1) & $\begin{array}{l}\text { bla }{ }_{O X A 51}, b a_{A D C}, b l a_{O X A 23}, b l a_{T E M-} \\
1, \operatorname{armA}, \operatorname{ant}\left(3^{\prime \prime}\right)-I\end{array}$ & $\begin{array}{l}\text { FEP, CRO, IPM, GEN, TOB, } \\
\text { LVX, CIP }\end{array}$ \\
\hline & & $A \vee(1)$ & 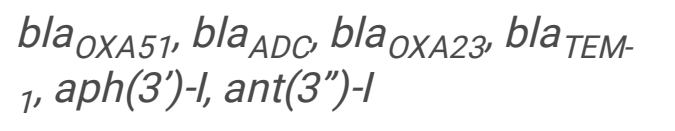 & $\begin{array}{l}\text { FEP, CRO, IPM, GEN, LVX, } \\
\text { CIP, SXT }\end{array}$ \\
\hline & & Avi (1) & 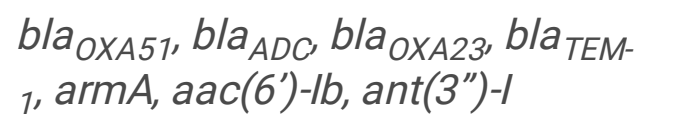 & $\begin{array}{l}\text { FEP, CRO, IPM, GEN, TOB, } \\
\text { LVX, CIP, SXT }\end{array}$ \\
\hline & & Avii (2) & $\begin{array}{l}\text { bla } \\
\text { }, \text { aXA51, } \\
\text { armA }\end{array}$ & $\begin{array}{l}\text { FEP, CRO, IPM, GEN, TOB, } \\
\text { LVX, CIP, SXT }\end{array}$ \\
\hline & & Aviii (1) & $\begin{array}{l}\text { bla } \\
\text {, }{ }_{\text {a A } A 51}, \text { bla }\left(3^{\prime}\right)-1\end{array}$ & $\begin{array}{l}\text { FEP, CRO, IPM, LVX, CIP, } \\
\text { SXT }\end{array}$ \\
\hline & & $\operatorname{Aix}(1)$ & bla $_{O X A 51}, b a_{A D C}, b l a_{O X A 23}$, ant $\left(3^{\prime \prime}\right)-l$ & FEP, CRO, IPM, LVX, CIP \\
\hline B & $\begin{array}{l}1 \\
(1.05)\end{array}$ & - & bla $_{O X A 51}, b a_{A D C}, b l a_{O X A 23}$, armA & FEP, CRO, IPM, SXT \\
\hline C & $\begin{array}{l}1 \\
(1.05)\end{array}$ & - & $b a_{O X A 51}, b l a_{A D C}$ & CRO \\
\hline D & 1 & - & bla ${ }_{O X A 51}, b_{A D C}$, aph $\left(3^{\prime}\right)-1, \operatorname{ant}\left(3^{\prime \prime}\right)-I$ & CRO, GEN, LVX, CIP, SXT \\
\hline
\end{tabular}




\begin{tabular}{|c|c|c|c|c|}
\hline$E$ & $\begin{array}{l}1 \\
(1.05)\end{array}$ & - & $b l a_{O X A 51}, b l a_{A D C}$ & CRO, CIP \\
\hline $\mathrm{F}$ & $\begin{array}{l}1 \\
(1.05)\end{array}$ & - & $b a_{O X A 51}, b l a_{A D C}, b l a_{T E M-1}$ & $\begin{array}{l}\text { FEP, CRO, IPM, GEN, TOB, } \\
\text { LVX, CIP, SXT }\end{array}$ \\
\hline G & $\begin{array}{l}1 \\
(1.05)\end{array}$ & - & bla $_{O X A 23}, b_{\text {TEM-1 }}, \operatorname{armA}, \operatorname{aph}\left(3^{\prime}\right)-1$ & $\begin{array}{l}\text { FEP, CRO, IPM, GEN, TOB, } \\
\text { LVX, CIP }\end{array}$ \\
\hline $\mathrm{H}$ & $\begin{array}{l}1 \\
(1.05)\end{array}$ & - & bla ${ }_{O X A 51}, b l a_{A D C}, a p h\left(3^{\prime}\right)-I$ & CRO \\
\hline I & $\begin{array}{l}1 \\
(1.05)\end{array}$ & - & $b l a_{O X A 51}, b l a_{A D C}$ & CRO \\
\hline J & $\begin{array}{l}1 \\
(1.05)\end{array}$ & - & $b a_{O X A 51}, b / a_{A D C}$ & CRO, CIP, SXT \\
\hline
\end{tabular}

${ }^{a}$ All isolates were tested negative for bla $a_{S H V}, b / a_{V I M-2}, b / a_{I M P}, b / a_{N D M N}, b / a_{O X A 58,}, b / a_{O X A 24}$; ${ }^{b} \mathrm{R}+\mathrm{I}$ : Resistant and intermediate;

Figures 

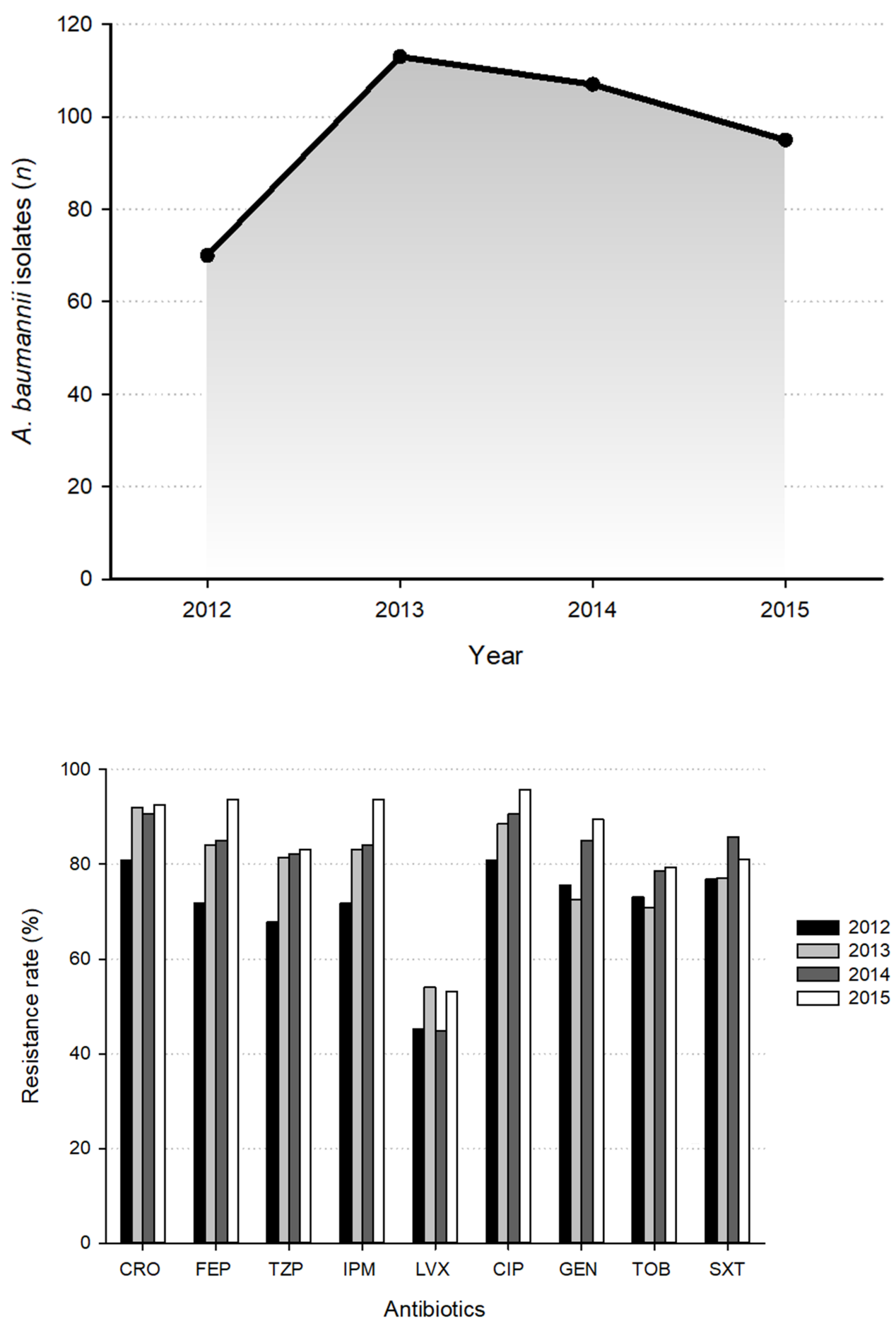

Figure 1

Distribution of A. baumannii isolates recovered at the ICU (upper panel) and their resistance rates for individual antibiotics (lower panel) over the period of 2012 to 2015. 


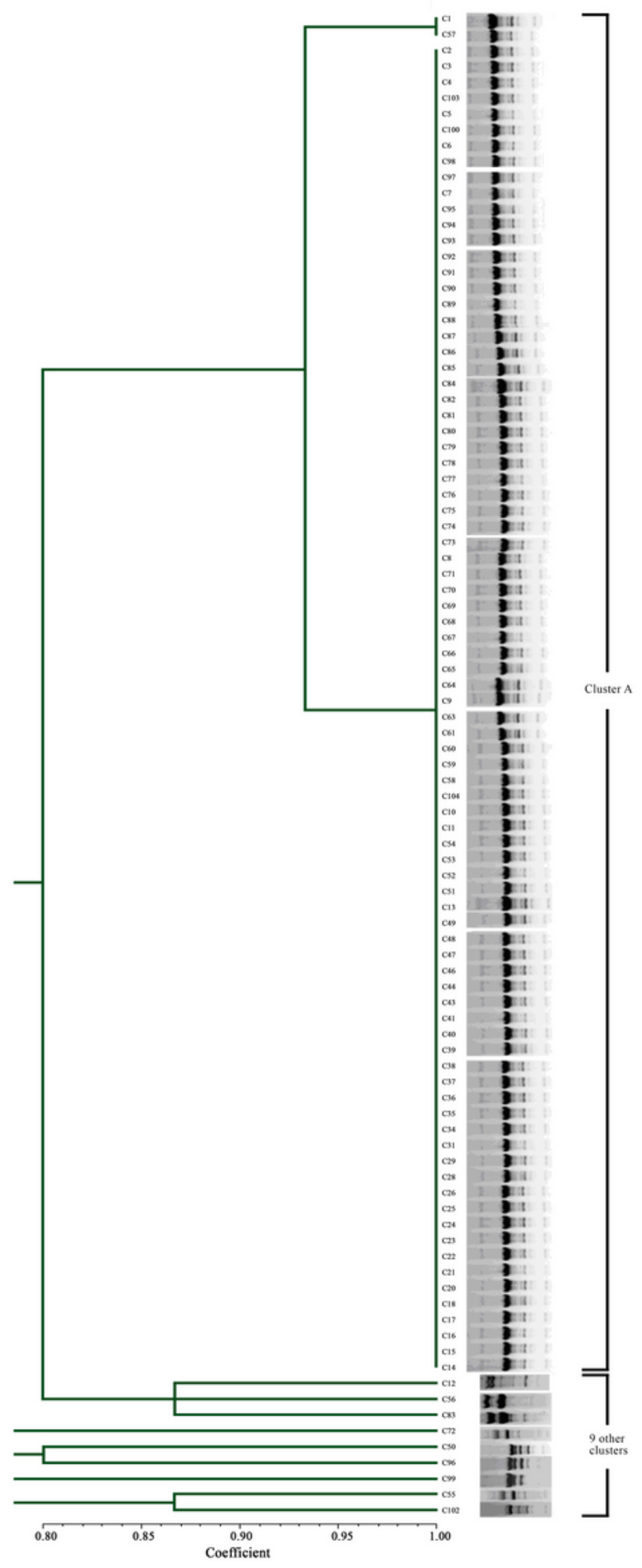

Figure 2

Dendrogram depicting genetic relationships of $A$. baumannii isolates. 